\title{
Development of E-Learning Modules for Information Systems Studies Based on Balinese Local Wisdom
}

\section{Agus Aan Jiwa Permana ${ }^{*}$, I Nyoman Laba Jayanta ${ }^{2}$}

1. Informatics Management, Faculty of Engineering and Vocational, Universitas Pendidikan Ganesha

${ }^{2}$ Elementary School Teacher Education, Faculty of Education, Universitas Pendidikan Ganesha

A R T I C L E I N F O

Article history:

Received 15 August 2019

Received in revised

Form 29 September 2019

Accepted 18 October 2019

Available online 29

November 2019

Keywords:

E-Learning, Tourism

Information System,

Local Genius Bali,

Learning Tools

\section{A B S T R A C T}

The learning process in college is not just reading material, doing assignments, collecting assignments, and then completing. If it is examined closely with the material presented it can be tedious and after the learning process does not increase students' knowledge. The most likely thing to do is to improve teaching material in an innovative direction that can improve graduate competency. So based on the 2016 curriculum, a Tourism Information System (TIS) course appears. Students who graduate need to be provided with knowledge about this TIS, especially because in Bali it is a world tourist destination.In realizing this, learning tools are needed to help, so a module is created to help the learning process that integrates SIP with the local culture of Bali to produce more attractive promotions that are accessed in $\mathrm{E}$ learning. 


\section{Introduction}

The development of information technology is currently very supportive of students to get lecture material easily. The development of various learning tools makes it easier for students to understand in learning. One way to develop learning tools is to make module teaching materials. Module development is carried out by adjusting with lecture material, students' characteristics, and learning conditions. The Information Management diploma program aims to prepare graduates who are ready to work.

The change in the 2012 curriculum to the 2016 curriculum gave rise to a new course called Tourism Information Systems. The emergence of this course aims to provide students the ability to develop application programs for use in the tourism sector including hotels, villas, finance, promotions, reservations, transportation, and making tour packages. With the development of technology now, creating a website and developing applications is no longer a big problem. Websites can be developed using open source technology, and financial applications are also sold at affordable prices.

This greatly reduces the work as a programmer, so in addition to developing applications students must also be taught to carry out promotions effectively both with brochures or online. Based on observations, in addition to an attractive website appearance also required writing interesting content. When developing a website for promotion that contains menus, then pictures, and improvised writing and location maps, now this is normal. Now many people who develop have developed websites with such models and not necessarily graduates of information technology.

With the emergence of new tourist attractions in villages and mountains, it opens our horizons to find out what exactly is interesting from that location. Why do people who live in cities now like to play to lonely places, mountains, see the sea, lakes, hills, mountains, cross rivers, climb trees, play swings in trees, play in the mud, catch fish in ponds, and many other types of activities others related to nature and culture.

This indicates that people are now bored of going to the Mall, watching the cinema, eating at restaurants, hanging out and drinking coffee at the Café. Now what's interesting about tourist sites is by showing local culture. There are many local cultures in Bali that are commonly used for the vision and mission of an agency and organization for example Tri Hita Karana, Tri Angga, Nyegara-Gunung where all can relate to nature and the environment.

Based on the explanation above, in developing material for the Tourism Information System (TIS) module, it should be able to increase the creative power of students to develop TIS content based on local culture. So that when graduating, students can apply their knowledge in the community to create tour packages, promote tourist attractions based on local Balinese culture.

The suitable learning method applied for the development of this module's teaching materials is project-based learning so that it helps students to come up with innovative ideas to develop applications and content from TIS. The learning process will be assisted by using e-learning, so that access to information for students is flexible and can collect assignments and access material from anywhere and anytime according to instructions. By using e-learning, it will be able to provide challenges to students to work on all projects properly in accordance with the time allotted and the instructions available.

TIS learning based on local culture will be packaged in a module teaching material with e-learning as a liaison between teachers and students. The expected outcome of the development of this module is to provide challenges and new knowledge to students in developing TIS applications based on local Balinese culture so as to preserve Balinese culture for the young generation amidst global cultural attacks. The culture now seems to be unlimited and many people do not know their own culture and even forget the existing culture. It seems like there are no more barriers between cultures. With this module students are expected to be able to think critically and still improve their hard skills.

\section{Methods}

There are several studies related to the topics discussed, such as the following Sindu and Pradnyana (2018) conducted a research by developing e-learning content in Multimedia courses with project-based learning methods. The result is material that is packaged in several meetings and students are asked to solve problems according to real events by way of discussion. Other research that develops elearning is on the subject of Information and Communication Technology at SMAN 3 Kupang. With this product it can be seen an increase in learning outcomes of students through the test of media validity in both categories (Helianak and Surjono, 2014). Hariyanto (2013) conducted a research by developing a web service based tourism information system. Application developed to facilitate communication between systems by using internet media to improve information, data and transaction services in the world of tourism. Nurdiawan, et al. (2012), developed an application to access tourist sites using google 
maps in the city of Cilacap so that visitors can find out what attractions there and their facilities. Fajri (2013) developed a module to improve learning outcomes in drawing 3D CAD in SMK 10 Semarang and the results of this study were an increase in student activity.

\section{Project Based Learning}

The characteristic of Project Based Learning (PjBL) is that it provides problems in the real world to become material in learning activities, where students must be able to solve problems, design, develop solutions and products (Education101, 2018). PjBL tends to be associated with teaching in vocational schools that starts with an essential or guiding question. Requires a long completion time from weeks because it is oriented to the product as the final result in the form of models, prototypes, posters, shows and so on. The next stage is the evaluation of the product produced by monitoring the progress of the project and providing guidance when needed. Then students report the product being developed then proceed with evaluation.

\section{E-learning}

Along with the use of information technology for education, the famous concept of e-learning is transforming conventional educational processes into online forms. e-learning can be used to help provide teaching materials to students using the internet. Currently this concept has been accepted by the community, schools, and campuses to help the learning process. Regulations for e-learning are being discussed at the ministry level. However, because in Indonesia the emphasis is on character-based education, the model used is Blenden Learning. Blended Learning is a combination of learning that is done face-to-face and virtually (Sevima, 2018). Helianak and Surjono (2014) say the e-learning function can be as a complement or additional, and in certain conditions can be as an alternative to other learning in the classroom. Now what is needed is a commitment from the teacher and students who make the rules at the beginning of the lecture that online lecture recognition is the same as face-to-face lectures in class.

\section{Wisdom and local culture}

Wisdom and local culture are ways of thinking and acting for the community in certain cultural arenas, both in their groups and in their relationships with the government. Its value is dynamic and has changed throughout time (Kuswandoro, 2015). Local wisdom in Bali is inherent in Balinese society. Bali has several traditions that are still held firm today and later. Bali has diverse religions and cultural acculturation that does not dampen the kinship of the people both physically and mentally. So that the terms "nyame selam" and "nyame bali" appear, meaning brothers of Islam and brothers of Bali. Examples of local wisdom bali megibung (eating together with rice and side dishes in one container), stump pengatag / tump bubuh (a form of affection for the universe, especially plants as a food source) (Payuyasa, 2017).The concept of "Nyegara Gunung" has a very large meaning towards nature conservation, especially to become a mountain and ocean as a sacred area to hold religious rituals. This is good for managing coral reefs on the island of Bali as well as the preservation of sea turtles (Kompas, 2017). Then related to the case of garbage that pollutes the sea in Bali, commemorating Earth Day students and the public are invited to manage the sea area with the concept of "Nyegara Gunung" because the garbage coming from upstream will definitely go to the ocean (Balipost, 2017). The Tri Hita Karana concept is a Balinese local counsel that has been adopted by the world at the 6th Global Forum of the United Nations Alliance of Civilizations. This concept is about a harmonious relationship between humans, humans and nature, and humans and creators (Antara, 2014).

\section{Modules}

Modules are books written with the aim that students can learn independently of their contents about all the basic components of teaching materials. Modules describe the basic competencies achieved by students, with presentations that use good language and are equipped with illustrations. Modules can be used by students as study guides in class or independently. Students can complete units from one subcompetency to the next sub-competency. The use of modules in teaching and learning can generate interest and motivation to learn (Fajri, 2013).

This research is a descriptive quantitative research using a population or a specific sample and in this case the sample of students taking Tourism Information Systems. The descriptive method serves to provide a description or description of the object under study through the data that has been collected 
(Intansari, et al., 2018). In the process of developing research using the ADDIE model as shown in Figure 1. Development with this model consists of five stages namely Analysis, Design, Development, Implementation, and Evaluation.

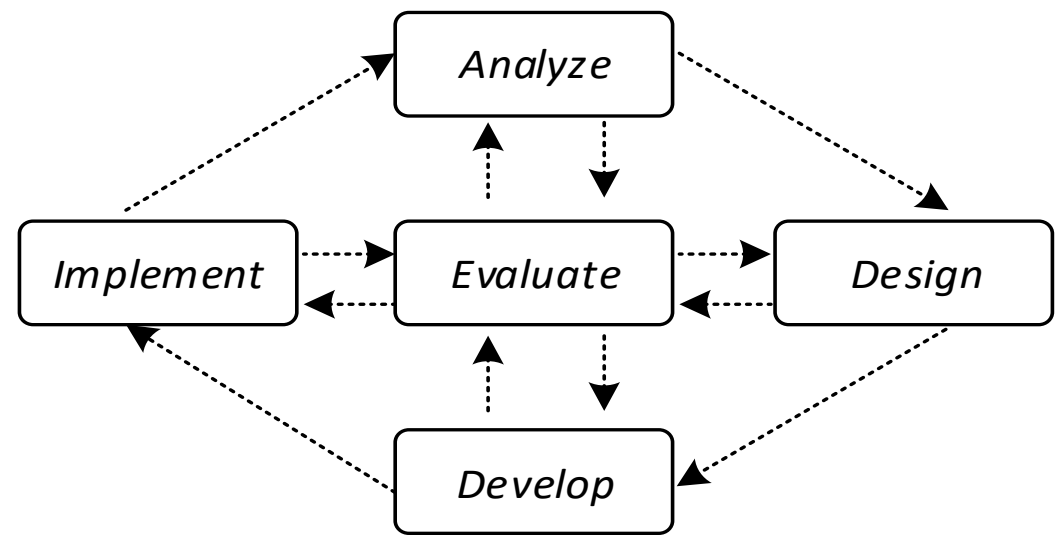

Figure 1. ADDIE Model

1. Analyze phase (analysis) is an activity to analyze courses related to the availability of learning resources, and analysis of learner characteristics

2. The Design Phase is used as a reference for the development of teaching materials, at this stage improvements are also made if there is a mismatch between the needs of the user and the developer, especially the development of the module content

3. The Development Phase in this section is developing modules by implementing project-based learning using e-learning for SIP courses based on local Balinese culture

4. Implementation phase in this part is carried out the implementation of modules that are made to be tested so that the e-modules developed are feasible or not. Testing can be done individually or in groups.

5. Evaluation Phase (Evaluation) Evaluation process is useful to find out whether the product being developed is in accordance with user needs so that competence is increased. The evaluation process is carried out on all stages so that the product developed can reach a predetermined standard

\section{Data Collection}

The data collection process was carried out by interviewing historians and cultural experts namely Dr. I Made Pageh, M.Hum to find out the concepts of Balinese local wisdom which would be suitable to be applied in TIS course material. In addition to the interview also sought literature from articles and books relating to SIP and Balinese Local Culture. After obtaining field data, it is then processed and entered into modules to become appropriate teaching materials plus enrich the content with pictures, graphics, questions and work instructions. So that modules can be seen to be more attractive to access. The modules developed have been tested with content experts and media experts to provide very extraordinary input in the development of this book.

\section{Result And Discussion}

The results of this study are modules that can be accessed on E-learning. Modules contain instructions that can be read by students, and then work on assignments independently. Learning outcomes obtained by the existence of this module are to improve students' thinking power in producing innovative products of critical thinking power to develop a tour package. After having the idea then developed into promotional media in the form of brochures, videos, and websites. The learning outcomes with this module are increasingly visible and can be implemented in project-based learning. This module can be accessed as shown in Figure 2. 




Figure 2. E-learning Modul of TIS

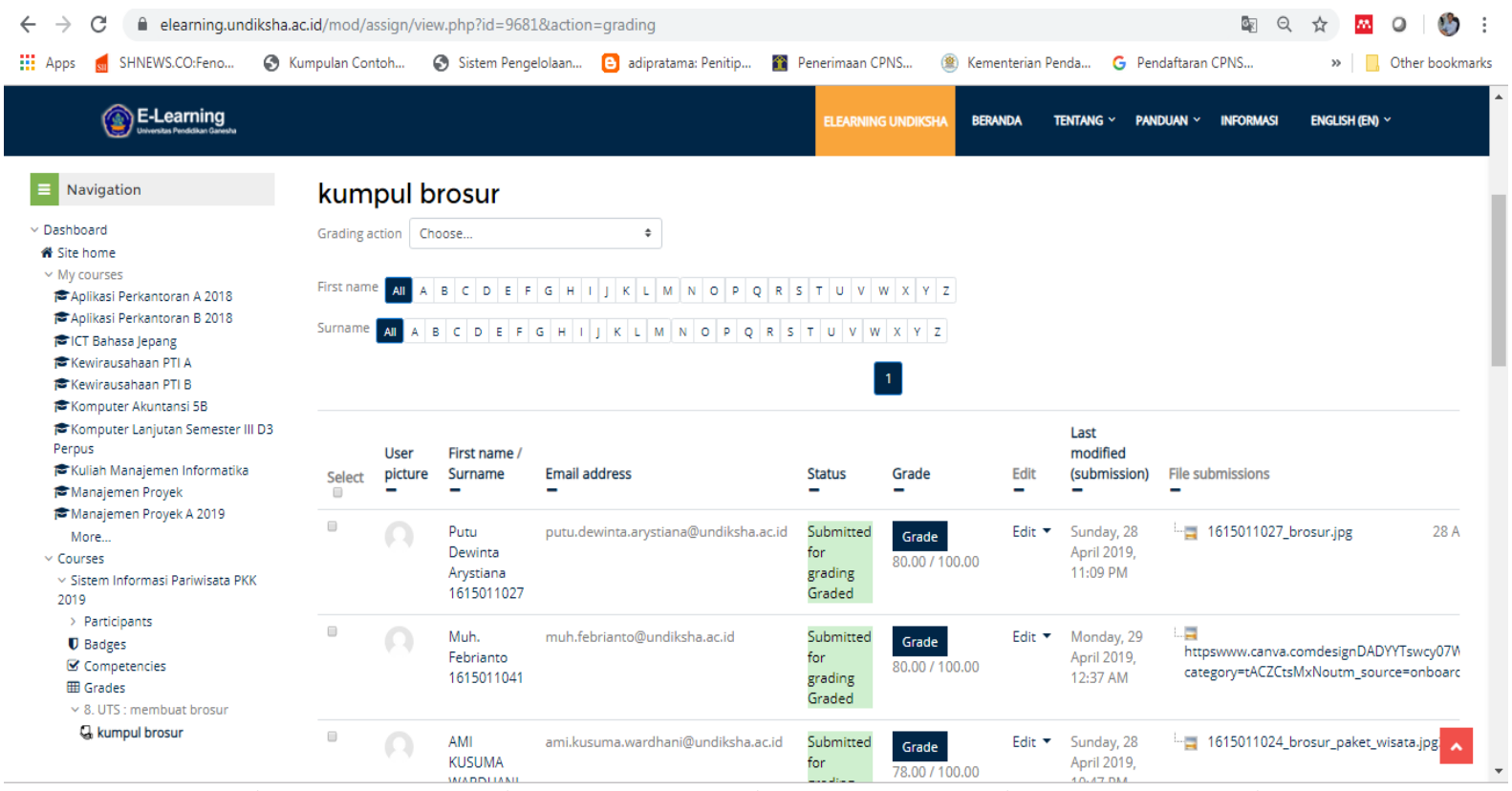

Figure 3. Evaluation Process

\section{Conclussion}

Module development has been successfully completed through root testing in terms of content and media. The module test results get decent results. Then the system is tested on students directly while in college. Students can follow the guidelines in the module and use e-learning that can be accessed independently. Users can access e-learning, read guides, do assignments, upload assignments, and see evaluations like Figure 3. Further module development can be revised according to technological developments and user needs. Technology is only a tool, the most important thing is to be able to highlight packages based on local wisdom to encourage the development of tourism in Bali.

\section{References}


Antara, 2014, Kearifan Lokal Bali Tri Hita Karana Diadopsi Dunia, diakses: 10/1/2019, https://www.wartaekonomi.co.id/read34454/kearifan-lokal-bali-tri-hita-karana-diadopsidunia.html

Balipost, 2017, Bali Harus Dikelola Dengan Konsep “Nyegara Gunung, diakses: 10/1/2019, http://www.balipost.com/news/2017/04/23/6422/Bali-Harus-Dikelola-dengan-Konsep...html

Edukasi101, 2018, Project Based Learning VS Problem Based Learning, diakses: 10/1/2019, https://edukasi101.com/2018/06/02/project-based-learning-vs-problem-based-learning/

Fajri, M.N., 2013, Pengembangan Perangkat Pembelajaran Moduluntuk Meningkatkan Hasil Belajar Menggambar Cad 3d Di Smk Negeri 10 Semarang, Pendidikan Teknik Mesin Fakultas Teknik Universitas Negeri Semarang, Skripsi

Hariyanto, A., 2013, Perancangan Sistem Informasi Pariwisata Indonesia Berbasis Web Services, Seminar Nasional Informatika 2013 (semnasIF 2013) UPN "Veteran" Yogyakarta, 18 Mei 2013 ISSN: 19792328.

Helianak, A.S, Surjono, H.D., 2014, Pengembangan e-learning Mata Pelajaran Teknologi Informasi Dan Komunikasi (Tik) Di SMA NEGERI 3 KUPANG, Jurnal Inovasi Teknologi Pendidikan, Volume 1 Nomor 1.

Intansari, M, Herwiyanti, R.D, Nurcahyo, A.R, Khakim, M.A, 2018, MAKALAH DESAIN PENELITIAN KUANTITATIF DESKRIPTIF, diakses : 9/1/2019, https://www.academia.edu/36311890/MAKALAH_DESAIN_PENELITIAN_KUANTITATIF_DESKRIP TIF.

Kompas, 2017, (Indonesia) Kearifan Lokal Warga Bali Jadi Fondasi Kuat, diakses: 10/1/2019, http://nyegaragunung.net/en/kearifan-lokal-warga-bali-jadi-fondasi-kuat/.

Kuswandoro, W., 2015, Kearifan dan Budaya Lokal (Local Wisdom): Integritas ala Indonesia, diakses: 10/1/2019, http://wkwk.lecture.ub.ac.id/2015/10/kearifan-dan-budaya-lokal-local-wisdomintegritas-ala-indonesia/.

Nurdiawan, T., Puncuna, I., Pudjoatmodjo, B., 2012, Aplikasi Informasi Pariwisata Berbasis Multimedia (Studi Kasus : Kota $\quad$ Cilacap), diakses : 10/1/2019, https://www.academia.edu/4024900/JURNAL_PA_APLIKASI_INFORMASI_PARIWISATA_BERBASIS _MULTIMEDIA?auto=download.

Payuyasa, I. N. 2017, Tumpek Uduh, Kearifan Lokal Baliuntuk Meningkatkan Mutu Pendidikan Karakter, Jurnal Penjaminan Mutu Lembaga Penjaminan Mutuinstitut Hindu Dharma Negeri Denpasar,Volume 3 Nomor 2 Agustus 2017, ISSN : 2407-912X (Cetak)ISSN : 2548-3110 (Online), http://ejournal.ihdn.ac.id/index.php/JPM.

Sevima, 2018, pengertian-dan-manfaat-model-pembelajaran-blended-learning, diakses: 10/1/2019, https://sevima.com/pengertian-dan-manfaat-model-pembelajaran- blended-learning/.

Sindu, I.G.P, Pradnyana, G.A., 2018, Rancangan Project Based E Learning Content Mata Kuliah Multimedia Di Jurusan PTI Undiksha, dipresentasikan dalam SENARI Undiksha ke-6, Denpasar 